\title{
Inhibitory Effects of Paraquat and Its Related Compounds on the Acetylcholinesterase Activities of Human Erythrocytes and Electric Eel (Electrophorus electricus)
}

\author{
Yasuo SETo and Toshiaki SHINOHARA \\ 2nd Chemistry Section, National Research Institute of Police Science, \\ Sanban-cho, Chiyoda-ku, Tokyo 102, Japan \\ Received March 11, 1987
}

\begin{abstract}
Paraquat inhibited the acetylcholinesterase activity of human erythrocytes and electric organs of Electrophorus electricus. The inhibition of acetylcholinesterase activity was reversible, as shown from the following two experimental results: [I] The degree of inhibition was not affected by changing the preincubation time of the enzyme and paraquat before the addition of the substrate. [II] The enzyme, preincubated with paraquat and subsequently freed from inhibitor by gel filtration on Sephadex G-25, showed the same activity as the untreated enzyme. Paraquat gave effective protection against the inhibition by an irreversible anionic site inhibitor, dibenamine, but not by irreversible esteratic site inhibitors, dichlorvos and methanesulfonyl chloride. These results indicate that paraquat functions as a reversible inhibitor for the anionic site. The inhibitory powers and Hill coefficients of paraquat and diquat were compared with the other quaternary ammonium compounds. Although secondary to edrophonium, paraquat strongly inhibited acetylcholinesterases of human erythrocytes and electric eel, and showed higher inhibition selectivity for both acetylcholinesterases than for human plasma butyrylcholinesterase. The Hill coefficients concerning the interaction of paraquat with acetylcholinesterases of human erythrocytes and electric eel were given as 0.83 and 0.73 , respectively. This indicates negative cooperativity between these enzymes and paraquat, which is similar to the case with $d$-tubocurarine. On the other hand, diquat showed weak inhibitory power and low inhibition selectivity, and its Hill coefficients were almost 1.0, indicating a competitive inhibition mode.
\end{abstract}

Paraquat (1,1'-dimethyl-4,4'-bipyridinium dichloride), which is widely used as nonselective contact herbicide, has recently raised the incidence of fatal toxicity in man and animal. Many studies of paraquat toxicity have been carried out with respect to functional damage to the lung, i.e., pulmonary edema leading to interstitial fibrosis. ${ }^{1)}$ The biochemical mechanism for the toxicity can be explained in terms of the peroxidation of membrane lipids, which is mediated through the transfer of a single electron from reduced paraquat to molecular oxygen and the subsequent formation of a superoxide anion. ${ }^{2)}$ The other biochemical effects of paraquat on animals have been reported to include diminution in lung surfactant, ${ }^{3)}$ inhibition of microsomal mixedfunction oxidase ${ }^{4)}$ and disturbance in carbo- hydrate metabolism. ${ }^{5)}$

Apart from the toxic mechanism of paraquat through its behavior as an oxido-redox compound, it seemed appropriate to investigate the pharmacological effect of paraquat in an in vitro experimental system, particularly since the pharmacological effect of paraquat on the central nervous system was yet unknown. Recently, we reported that paraquat inhibited acetylcholinesterase (AChE, EC 3.1.1.7) activity of human erythrocytes, but not acylcholinesterase (BuChE, EC 3.1.1.8) of human plasma in an in vitro experiment. ${ }^{6)}$ The former enzyme is generally found in the erythrocyte membrane and in neuronal synapses, and classified as a different enzyme from BuChE. ${ }^{7)}$ In the present study, we have clarified the inhibitory effects of paraquat and its 
structurally related compounds on the AChEs of human erythrocytes and electric eel (Electrophorus electricus).

\section{MATERIALS AND METHODS}

Chemicals. The following chemical reagents were purchased from Wako Pure Chemical Industries (Osaka, Japan): acetylthiocholine (ATCh) iodide, butyrylthiocholine iodide, 5,5'-dithio-bis(2-nitrobenzoic acid) (DTNB), eserine (physostigmine) sulfate, dichlorvos (dimethyl 2,2-dichlorovinyl phosphate), tetramethylammonium chloride and trimethylphenylammonium chloride. Dibenamine $(N, N$-dibenzyl- $\beta$-chlorethylamine) hydrochloride and methanesulfonyl chloride were purchased from Nakarai Chemicals (Kyoto, Japan). Edrophonium (ethyl[ $m$-hydroxyphenyl]dimethylammonium) chloride, electric eel AChE (Type IV-S) and bovine serum albumin (fraction $\mathrm{V}$ ) were purchased from Sigma Chemical Co. (St. Louis, U.S.A.). $d$-Tubocurarine chloride was obtained from Tokyo Chemical Co. (Tokyo, Japan), Sephadex G-25 (fine) was obtained from Pharmacia Fine Chemicals (Uppsala, Sweden). Paraquat dichloride and diquat $\left(1,1^{\prime}\right.$-ethylene-2,2'-bipyridinium) dibromide were supplied from ICI Japan Ltd. (Tokyo). The other chemicals used were of analytical reagent grade.

Preparation and solubilization of human erythrocyte ghosts. Erythrocyte ghosts were prepared according to the procedure of Dodge et al. ${ }^{8)}$ using outdated human erythrocytes in transfusion, and used for a smaple of erythrocyte AChE. Membrane-bound AChE was solubilized by combining one volume of the packed erythrocyte ghosts with three volumes of $0.167 \mathrm{M}$ Tris- $\mathrm{HCl}$ buffer ( $\mathrm{pH}$ 6.8) containing $0.667 \%$ (v/v) Triton X-100, and then stirring at $2^{\circ} \mathrm{C}$ for $1 \mathrm{hr}$. The solubilized solution was centrifuged $(100,000 \times g)$ at $2^{\circ} \mathrm{C}$ for $1 \mathrm{hr}$, and the supernatant thus obtained was used for the experiment.

Cholinesterase assay. Cholinesterase (ChE) activity was measured by the method of Ellman et al. ${ }^{9)}$ with some modification, as previously described. ${ }^{10)}$ For AChE activity, human erythrocyte ghosts and electric eel AChE were used as the enzyme sources. For BuChE activity, human plasma isolated from outdated human blood was used. One hundred $\mu \mathrm{l}$ of a diluted sample was added to $3 \mathrm{ml}$ of a $0.25 \mathrm{~mm}$ DTNB solution containing $20 \mathrm{~mm}$ sodium phosphate ( $\mathrm{pH} 7.7$ ), and the mixture was preincubated for $10 \mathrm{~min}$ at $25^{\circ} \mathrm{C}$ while being shaken. The enzyme reaction was started by adding a substrate to the preincubated solution, $10 \mu \mathrm{l}$ of $156 \mathrm{~mm}$ ATCh solution for $\mathrm{AChE}$ and $40 \mu \mathrm{l}$ of $156 \mathrm{~mm}$ butyrylthiocholine iodide solution for $\mathrm{BuChE}$ being added as the substrate reagent. Such a mixed assay solution was further incubated at $25^{\circ} \mathrm{C}$ for $15 \mathrm{~min}$ while being shaken. The enzyme reaction was stopped by adding $70 \mu \mathrm{l}$ of a $12 \mathrm{~mm}$ eserine solution. For the blank test, the eserine solution $(70 \mu \mathrm{l})$ was added prior to the enzyme reaction. The absorbance of the solution containing the liberated 5-thio-2-nitrobenzoate was measured at $405 \mathrm{~nm}$. ChE activity was calculated from a value of the extinction coefficient $(\varepsilon, 13500)$, and expressed as $\mathrm{U} / \mathrm{ml}$. One unit (U) represents the $\mathrm{ChE}$ activity hydrolyżing $1 \mu \mathrm{mol}$ of substrate per min. For the assay of electric eel AChE, $30 \mu \mathrm{l}$ of $10 \%$ (v/v) Triton X-100 was added to the reaction mixture to stabilize the enzyme activity.

In the inhibition assay for ChE activity, an inhibitor was added prior to the preincubation $(10 \mathrm{~min})$ of the enzyme reaction. The enzyme samples used were human erythrocyte ghosts $(70 \mu \mathrm{g}$ protein $/ \mathrm{ml}, 40 \sim 48 \mathrm{mU} / \mathrm{ml})$, electric eel AChE (400 ng protein/ml, $140 \sim 180 \mathrm{mU} / \mathrm{ml})$ and human plasma (diluted 50 -fold, $1.02 \sim 1.25 \mathrm{mg}$ protein $/ \mathrm{ml}$, $40 \sim 63 \mathrm{mU} / \mathrm{ml}$ ). The inhibitors used were dissolved in distilled water, except for dichlorvos, dibenamine and methanesulfonyl chloride, the latter three compounds being dissolved in absolute ethanol. The final ethanol concentration was minimized in the enzyme reaction mixture within $3 \%(\mathrm{v} / \mathrm{v})$. ChE activity without an inhibitor was assayed in the presence of an equal volume of ethanol for a control test. The rate of thiocholine formation in this assay proceeded linearly up to $20 \mathrm{~min}$, whether a reversible inhibitor was present in the reaction mixture or not. The level of ChE inhibition, the ratio of the $\mathrm{ChE}$ activities in the presence or absence of an inhibitor, did not vary during the $15 \mathrm{~min}$ reaction time. The inhibition level, given as the $I_{50}$ value, was expressed as the concentration of inhibitor necessary to cause $50 \%$ inhibition.

Hill coefficients and $I_{50}$ values could be calculated by using the Hill equation ${ }^{11}$ :

$$
\log [V o / V i)-1]=n_{\mathrm{H}} \log [\mathrm{I}]+\text { constant }
$$

where $V o$ and $V i$ are the activity in the absence and in the presence of an inhibitor, [I] is the inhibitor concentration, and $n_{\mathrm{H}}$ is the Hill coefficient. By plotting $\log [(V o / V i)-1]$ against $\log [\mathrm{I}]$ and by data analysis with the least-square linear regression, each $n_{\mathrm{H}}$ value was obtained from the slope of the fitted linear line. Also, the $I_{50}$ value was obtained from the inhibitor concentration corresponding to a value of 0 on the $\log [(V o / V i)-1]$ axis, as shown in Fig. 2.

Inactivation of acetylcholinesterase. The solubilized solution of human erythrocyte ghosts (final concentration of $0.16 \mathrm{mg}$ protein $/ \mathrm{ml}, 0.29 \mathrm{U} / \mathrm{mg}$ of protein) was incubated at $25^{\circ} \mathrm{C}$ with or without an inhibitor in a buffer solution (pH 7.7) containing $20 \mathrm{~mm}$ sodium phosphate and $0.1 \%$ (v/v) Triton X-100 (buffer A). For electric eel AChE, the enzyme solution (final concentration of $2 \mu \mathrm{g}$ protein $/ \mathrm{ml}$ ) was incubated in buffer A. The inhibitors used were paraquat, dichlorvos, methanesulfonyl chloride and dibenamine. The inhibitor was removed from the inhibitorconjugated AChE by gel filtration on a Sephadex G-25 column equilibrated with buffer $\mathrm{A}$ at $2^{\circ} \mathrm{C}$. An aliquot 
$(100 \mu \mathrm{l})$ of the incubation mixture was applied on the Sephadex G-25 column $(1 \times 22 \mathrm{~cm})$, and then eluted with buffer $A$ at a flow-rate of $4 \sim 5 \mathrm{ml} / \mathrm{hr}$. The void volume fraction containing the inhibitor-conjugated enzyme was collected. To the fraction $(3.18 \mathrm{ml})$ preincubated at $25^{\circ} \mathrm{C}$ for $10 \mathrm{~min}, 100 \mu \mathrm{l}$ of $10 \mathrm{~mm}$ DTNB solution and $10 \mu \mathrm{l}$ of $156 \mathrm{~mm}$ ATCh solution was added, and the mixed solution was further incubated for $15 \mathrm{~min}$. The enzyme reaction was stopped by adding $70 \mu \mathrm{l}$ of $12 \mathrm{~mm}$ eserine solution, and the AChE activity was measured as already described.

In the experiment for the 'protective effect' of paraquat, the enzyme solution was incubated with an irreversible inhibitor and paraquat. The detailed incubation conditions are described in the legend to Table II.

Protein assay. The protein contents of human plasma and erythrocyte ghosts were determined by a biuret reaction $^{12)}$ in the presence of $1.0 \%(\mathrm{w} / \mathrm{v})$ sodium deoxycholate in order to remove any turbidity in the sample solution. The microassay of the protein content in the solubilized solution of erythrocyte ghosts was carried out by the method of Lowry et al. ${ }^{13)}$ with the correction of an error caused by contamination by the detergent (Triton X-100). Bovine serum albumin was used as a standard protein.

\section{RESULTS}

\section{Reversibility of AChE inhibition}

As shown in Fig. 1, the degree of inhibition against the AChE activity (human stroma, A; electric eel, B) by dichlorvos was increased during the preincubation time from 0 to $100 \mathrm{~min}$, indicating an 'irreversible' inhibition. On the contrary, the degree of $\mathrm{AChE}$ inhibition by paraquat and diquat did not change over a period of $100 \mathrm{~min}$.

As shown in Table I, erythrocyte AChE preincubated with dichlorvos and subsequently separated from the excess inhibitor lost its activity to a great extent (about $67 \%$ of the AChE activity in the absence of an inhibitor), while erythrocyte AChE preincubated with paraquat and subsequently separated from excess inhibitor retained the same AChE

TABle I. REVERSIBILITY OF ACETYLCHOLINESTERASE INHIBITION BY PARAQUAT

\begin{tabular}{lcc}
\hline Inhibitor & $\begin{array}{c}\text { Human erythrocyte } \\
\mathrm{AChE}\end{array}$ & $\begin{array}{c}\text { Electric eel } \\
\mathrm{AChE}\end{array}$ \\
\hline None & 100 & 100 \\
Paraquat & 103.0 & 98.5 \\
Dichlorvos & 33.0 & 17.8 \\
\hline
\end{tabular}

The time of incubation with an inhibitor was $30 \mathrm{~min}$, and the final inhibitor concentration in the incubation mixture was $359 \mu \mathrm{M}$ for paraquat and $113 \mu \mathrm{M}$ for dichlorvos. Detailed experimental conditions are described in Materials AND Methods. Each value represents the percentage of AChE activity compared with the activity without inhibitors.

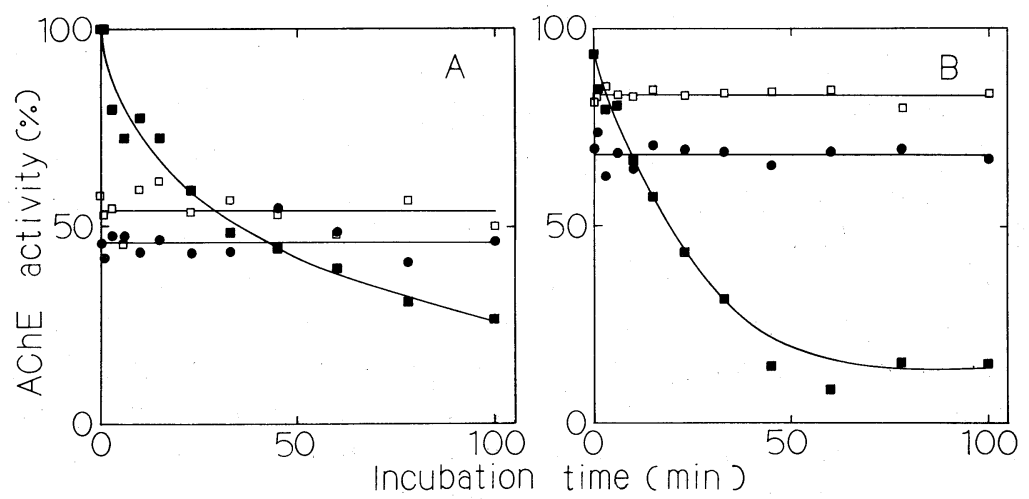

FIG. 1. Change of Acetylcholinesterase Activity with Preincubation Time in the Presence of Paraquat and Dichlorvos.

Enzyme solutions ( $100 \mu \mathrm{l}$ containing $7 \mu \mathrm{g}$ of human stroma protein, $15 \mathrm{mU}$ (A); $40 \mathrm{ng}$ of protein of electric eel AChE, $135 \mathrm{mU}(\mathrm{B}))$ were mixed with $3 \mathrm{ml}$ of $0.25 \mathrm{~mm}$ DTNB solution containing $20 \mathrm{~mm}$ sodium phosphate $(\mathrm{pH} 7.7)$ in the presence of paraquat $(\triangle \mathrm{A}, 30.9 \mu \mathrm{M} ; \mathrm{B}, 3.08 \mu \mathrm{M})$, diquat $(\square \mathrm{A}, 1.25 \mathrm{~mm} ; \mathrm{B}, 125 \mu \mathrm{M})$ and dichlorvos $(\square \mathrm{A}, 0.721 \mu \mathrm{M} ; \mathrm{B}, 1.43 \mu \mathrm{M})$. After incubation $(0 \sim 100 \mathrm{~min})$ at $25^{\circ} \mathrm{C}$ with an inhibitor, the $\mathrm{AChE}$ activities were measured. The residual activity is expressed as a percentage compared with the activity without an inhibitor. 
Table II. Protective Effect of Paraquat against the Irreversible Inhibition OF ACETYLCHOLINESTERASE

\begin{tabular}{clcc}
\hline & & Human erythrocyte & Electric eel \\
& & AChE & AChE \\
\hline \multirow{3}{*}{ Exp. 1 } & Control & 100 & 100 \\
& Dibenamine & 18.5 & 18.3 \\
& Dibenamine + paraquat & 82.3 & 86.7 \\
\hline \multirow{3}{*}{ Exp. 2 } & Control & 100 & 100 \\
& Dichlorvos & 33.0 & 17.7 \\
& Dichlorvos + paraquat & 24.8 & 15.4 \\
\hline \multirow{2}{*}{ Exp. 3 } & Control & 100 & 100 \\
& MSC & 44.7 & 15.1 \\
& MSC + paraquat & 44.7 & 0.0 \\
\hline
\end{tabular}

Incubation conditions were as follows: Exp. 1, each enzyme solution was incubated for $170 \mathrm{~min}$ at $25^{\circ} \mathrm{C}$ with dibenamine $(495 \mu \mathrm{M})$ alone or with dibenamine $(495 \mu \mathrm{M})$ and paraquat $(5.29 \mathrm{~mm})$; Exp. 2, for 30 min with dichlorvos $(113 \mu \mathrm{M})$ alone or with dichlorvos $(113 \mu \mathrm{M})$ and paraquat $(970 \mu \mathrm{M})$; Exp. 3, for 30 min with methanesulfonyl chloride $(6.14 \mathrm{~mm})$ alone or with methanesulfonyl chloride $(6.14 \mathrm{~mm})$ and paraquat $(44.5 \mathrm{~mm})$. An aliquot of the incubation mixture was applied to gel filtration. The experimental conditions are described in MATERIALS AND METHODS. Each value represents the percentage of AChE activity compared with the activity in the absence of the inhibitors.

a Methanesulfonyl chloride.

activity as in the control experiment without an inhibitor. A similar result was obtained in the experiment with electric eel AChE (Table I).

Binding site of paraquat in the AChE molecule As shown in Table II, dibenamine, dichlorvos and methanesulfonyl chloride produced inactivation of both human erythrocyte and electric eel AChEs. However, the addition of paraquat to the preincubation mixture of $\mathrm{AChE}$ and dibenamine alleviated the inactivation by dibenamine. On the contrary, the addition of paraquat to the preincubation mixture of $\mathrm{AChE}$ and dichlorvos (or methanesulfonyl chloride) did not retard the extent of such inactivation. Moreover, the levels of inactivation of dichlorvos and methanesulfonyl chloride were increased by adding paraquat.

Comparison of $I_{50}$ values with the other quaternary ammonium compounds

As shown in Fig. 2, Hill plots of the inhibition against human erythrocyte (A) and electric eel (B) AChE's by paraquat, $d$ - tubocurarine and edrophonium were linear within a concentration range from about -1 to about 1 on the $\log [(V o / V i)-1]$ axis (corresponding to about $10 \sim 90 \%$ inhibition of enzyme activity). Table III illustrates the $I_{50}$ values of the quaternary ammonium compounds for human erythrocyte AChE, electric eel AChE and human plasma BuChE activities. These compounds mostly showed stronger inhibitory effects on AChEs of human erythrocyte and electric eel compared with human plasma BuChE. The ratio of $I_{50}$ for human plasma $\mathrm{BuChE}$ and that for human erythrocyte AChE may explain the inhibition selectivity of $\mathrm{AChE}$ to BuChE. Edrophonium, known as a muscle stimulant, had the strongest inhibitory power and the highest inhibition selectivity on AChE activity among the quaternary ammonium compounds. Paraquat possessed strong inhibitory power, the same level as that of $d$-tubocurarine, known as a skeletal muscle relaxant, and had inhibition selectivity as high as trimethylphenylammonium. On the other hand, diquat showed weak inhibition selectivity, and its inhibition power was between 
TABLE III. COMPARISON BETWEEN THE INHIBITORY POWERS OF Quaternary AMmonium COMPOUNDS ON CHOLINESTERASES

\begin{tabular}{|c|c|c|c|c|c|}
\hline \multirow[b]{2}{*}{ Inhibitor } & \multicolumn{5}{|c|}{ ChE } \\
\hline & $\begin{array}{c}\text { Human } \\
\text { erythrocyte } \\
\text { AChE (A) }\end{array}$ & $\begin{array}{c}\text { Human } \\
\text { plasma } \\
\text { BuChE (B) }\end{array}$ & $\begin{array}{c}\text { Electric } \\
\text { eel } \\
\mathrm{AChE}\end{array}$ & Ratio & $\frac{\text { (B) }}{\text { (A) }}$ \\
\hline Paraquat & 29 & 7,900 & 6.1 & 270 & \\
\hline Diquat & 1,500 & 9,800 & 580 & 6.6 & \\
\hline$d$-Tubocurarine & 63 & 350 & 56 & 5.5 & \\
\hline Edrophonium & 0.87 & 1,300 & 0.37 & 1,500 & \\
\hline Trimethylphenylammonium & 150 & 29,000 & 110 & 190 & \\
\hline Tetramethylammonium & 11,000 & 87,000 & 4,500 & 8.1 & \\
\hline
\end{tabular}

Each value represẹts $\mathrm{I}_{50}(\mu \mathrm{M})$.

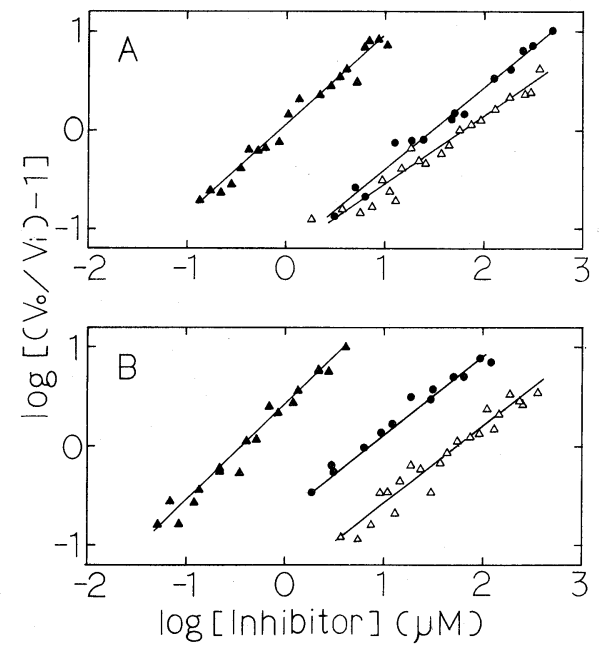

FIG. 2. Hill Plot of the Acetylcholinesterase Interaction with Quaternary Ammonium Compounds.

The enzyme solution ( $100 \mu \mathrm{l}$ containing $7 \mu \mathrm{g}$ of human stroma protein, $4.0 \sim 4.8 \mathrm{mU}$ (A); $40 \mathrm{ng}$ of protein of electric eel AChE, $14 \sim 18 \mathrm{mU}(\mathrm{B}))$ was mixed with $3 \mathrm{ml}$ of $0.25 \mathrm{~mm}$ DTNB solution containing $20 \mathrm{~mm}$ sodium phosphate ( $\mathrm{pH}$ 7.7) in the presence of an inhibitor. After $10 \mathrm{~min}$ of incubation, $10 \mu \mathrm{l}$ of $156 \mathrm{~mm}$ ATCh solution was added to the mixture, which was further incubated for $15 \mathrm{~min}$ at $25^{\circ} \mathrm{C}$. The reaction was stopped by adding $70 \mu \mathrm{l}$ of $12 \mathrm{mM}$ eserine solution. The residual AChE activity ( $V i)$ was compared to that without an inhibitor $(V o)$. The inhibitors used were paraquat $(\circlearrowleft), d$-tubocurarine $(\triangle)$ and edrophonium $(\boldsymbol{\Delta})$. The straight lines were fitted to these data by the least-squares linear regression.

that of trimethylphenylammonium and tetramethylammonium.
Table IV. Comparison between Hill Coefficients OF QUATERnARY AMMONIUM COMPOUNDS FOR ACETYLCHOLINESTERASES

\begin{tabular}{lcc}
\hline \multirow{2}{*}{ Inhibitor } & \multicolumn{2}{c}{ AChE source } \\
\cline { 2 - 3 } & $\begin{array}{c}\text { Human } \\
\text { erythrocyte }\end{array}$ & $\begin{array}{c}\text { Electric } \\
\text { eel }\end{array}$ \\
\hline Paraquat & 0.83 & 0.73 \\
Diquat & 0.95 & 1.06 \\
-Tubocurarine & 0.69 & 0.78 \\
Edrophonium & 0.90 & 0.96 \\
Trimethylphenylammonium & 0.94 & 0.96 \\
Tetramethylammonium & 1.04 & 0.97 \\
\hline
\end{tabular}

Comparison of Hill coefficients with the other quaternary compounds

Hill coefficients of these quaternary ammonium compounds just mentioned are summarized in Table IV. The values of $d$ tubocurarine were given as 0.69 and 0.78 for human erythrocyte and electric eel AChEs, respectively. Paraquat also showed small values, less than 1.0, for both AChEs, which indicates negative cooperativity, the same as that of $d$-tubocurarine. On the other hand, the Hill coefficients of the other compounds, diquat, trimethylphenylammonium, tetramethylammonium and edrophonium, were all close to 1.0 for both AChEs.

\section{DISCUSSION}

Most organophosphorus and carbamate 
pesticides are known to inhibit $\mathrm{ChE}$ activity by covalent binding to the active center of the ChE molecule, resulting in irreversible inhibition. ${ }^{14)}$ On the other hand, from our two experimental results (Fig. 1 and Table I) we can conclude that $\mathrm{AChE}$ inhibition by the herbicides, paraquat and diquat, is reversible.

Because the ChE molecule is known to possess two sites in its active center, $\left.{ }^{15}\right) \mathrm{ChE}$ inhibitors can be divided into two groups: an anionic site inhibitor and an esteratic site inhibitor, although some inhibitors have binding affinity for both sites. Dibenamine is converted to ethyleniminium ions possessing quaternary ammonium ion structures, and forms reversible addition complexes with the anionic site, and binds covalently to $\mathrm{AChE}$ at or near the anionic site (alkylation) ${ }^{16)}$; methanesulfonyl chloride ${ }^{17)}$ and dichlorvos ${ }^{14)}$ are covalently bound to the hydroxyl group of serine in the esteratic site. Table II shows that paraquat bound to the anionic site and protected sterically against the attack of an irreversible inhibitor on the anionic site, but did not protect against the attack on the esteratic site. This results suggests that paraquat competitively bound to the anionic site, which is in agreement with the observation of Belleau and Tani, ${ }^{18)}$ who demonstrated that tetramethylammonium iodide, a competitive inhibitor, retarded irreversible inactivation by $N, N$-dimethyl-2-chloro-2-phenethylamine. The level of the inhibitory effect of the irreversible esteratic inhibitors was increased with the addition of paraquat. This is compatible with other reports, ${ }^{19,20)}$ which demonstrate that masking of the anionic site by some quaternary ammonium ion had a marked accelerating effect on the rate of sulfonylation $^{19)}$ and carbamylation ${ }^{20}$ of the esteratic site.

Some kinds of quaternary ammonium compounds are well known as reversible inhibitors possessing an affinity for the anionic site of the active center. ${ }^{21)}$ Because paraquat and diquat are regarded as quaternary ammonium compounds, it may be significant to compare the inhibitory effects of these herbicides on $\mathrm{ChE}$ activity with the other quaternary ammonium compounds. Edrophonium showed the highest inhibitory power and the highest inhibition selectivity on AChE activity. This strong inhibition probably derives from its molecular structure: the quaternary ammonium portion has a binding affinity to the anionic site, and the hydroxyl group sterically positioned to the esteratic site forms a hydrogen bond, perhaps with the imidazole group of the esteratic site. ${ }^{22)}$ Although secondary to edrophonium, paraquat showed stronger inhibitory power and higher inhibition selectivity on $\mathrm{AChE}$ activity. Inhibition selectivity refers to the difference between the binding affinity of the inhibitor to the anionic site of each $\mathrm{ChE}$ molecule. It is concluded that paraquat bound to an anionic site of AChE strongly and selectively, compared to BuChE.

It has been reported that some divalent quaternary ammonium compounds can bind to two sites of $\mathrm{AChE}$, not only to the anionic site of the active center, but also to another anionic site. ${ }^{23)}$ The latter site may be an allosteric (regulatory) site, which causes a conformational change to the $\mathrm{AChE}$ molecule, resulting in an alteration of the $\mathrm{AChE}$ active site. $^{24)} d$-Tubocurarine, a typical pachycurare, gave a value less than 1.0 for the Hill coefficients, which is compatible with the reports of Moss et al. ${ }^{25)}$ and Zorko et al. ${ }^{26)}$ As the Hill coefficients for paraquat were less than 1.0 , it is possible to assume that paraquat can bind not only to the anionic site of the active center but also to another site, which suggests negative cooperativity. On the other hand, diquat showed about 1 for the Hill coefficients, indicating that it bound only to an anionic site of the active center in both enzymes.

Toxicologically, it has been reported that the peak concentration of paraquat in blood was $22 \mu \mathrm{g} / \mathrm{ml}$ for rat, $5 \mu \mathrm{g} / \mathrm{ml}$ for guinea-pig and $70 \mu \mathrm{g} / \mathrm{ml}$ for cat. ${ }^{27)}$ Because the $\mathbf{I}_{50}$ value of paraquat for human erythrocyte $\mathrm{AChE}$ was $29 \mu \mathrm{M}(7.4 \mu \mathrm{g} / \mathrm{ml})$ in a clinical case of paraquat poisoning, it is uncertain whether the erythrocyte $\mathrm{AChE}$ is inhibited in vivo. Also, the 
physiological function of erythrocyte $\mathrm{AChE}$ has not been clearly elucidated. ${ }^{28)}$ From the results of this experiment, it remains uncertain whether the toxicity of paraquat is related to the inhibition of erythrocyte AChE activity or not.

It seems plausible that paraquat can inhibit the nervous AChE influentially in addition to the inhibitory effect on human erythrocyte and electric eel AChEs. However, it may be difficult to infer that paraquat can enter the brain through the blood-brain barrier because of its cationic and hydrophilic nature. Litchfield et al. demonstrated that in rats, both paraquat and diquat were rapidly distributed throughout most tissues except for the brain and spinal cord ${ }^{29)}$ However, if paraquat partly enters the cholinergic junctions in the periphery, it may disturb normal nervous transmission at the synapses. Accordingly, the toxicity of paraquat and diquat may be associated with the inhibition of AChE.

Recently, 1-methyl-4-phenyl-1,2,3,6-tetrahydropyridine (MPTP) has been found to induce a parkinsonian-like syndrome in humans and some animals, ${ }^{30)}$ and its neuronal toxicity is explained as being derived from 1methyl-4-phenylpyridinium $\left(\mathrm{MPP}^{+}\right)$that is converted from MPTP by the action of monoamineoxidase. ${ }^{31)}$ As paraquat is so structurally similar to $\mathrm{MPP}^{+}$, it is thought to have a toxicity similar to $\mathrm{MPP}^{+} .{ }^{32,33)}$ Considering the two observations of the neuronal toxicity of $\mathrm{MPP}^{+}$and the similarity of the chemical structure, it will be of much pharmacobiochemical interest to investigate the effect of paraquat on the nervous system such as the cholinergic and dopaminergic neurons.

\section{REFERENCES}

1) A. Pasi, "The Toxicology of Paraquat, Diquat and Morfamquat," Hans Huber Publishers, Switzerland, 1978.

2) J. S. Bus, S. D. Aust and J. E. Gibson, Biochem. Biophys. Res. Commun., 58, 749 (1974).

3) B. W. Manktelow, Br. J. Exp. Pathol., 48, 366 (1967).

4) R. I. Krieger, P. W. Lee, A. Black and T. R. Fukuto, Bull. Environ. Contam. Toxicol., 9, 1 (1973).
5) M. S. Rose, H. C. Crabtree, K. Fletcher and I. Wyatt, Biochem. J., 138, 437 (1974).

6) T. Shinohara and Y. Seto, Agric. Biol. Chem., 50, 255 (1986).

7) International Union of Biochemistry, "Report of the Commission on Enzyme 1961," Pergamon Press, Oxford, 1964, p. 104.

8) J. T. Dodge, C. Mitchell and D. J. Hanahan, Arch. Biochem. Biophys., 100, 119 (1963).

9) G. L. Ellman, K. D. Courtney, V. Andres, Jr. and R. B. Featherstone, Biochem. Pharmacol., 7, 88 (1961).

10) T. Shinohara and Y. Seto, Repts. Natl. Res. Inst. Police Sci., 38, 178 (1985).

11) R. B. Loftfield and E. A. Eigner, Science, 164, 305 (1969).

12) A. G. Gornall, C. J. Bardaeill and M. M. David, J. Biol. Chem., 177, 751 (1949).

13) O. H. Lowry, N. J. Rosebrough, A. L. Farr and R. J. Randall, J. Biol. Chem., 193, 265 (1951).

14) W. N. Aldridge, "Enzyme Inhibitors as Drugs," ed. by M. Sandler, MacMillan Press, London, 1980, pp. $115 \sim 125$.

15) I. B. Wilson and F. Bergmann, J. Biol. Chem., 185, 479 (1950).

16) F. Beddoe and H. J. Smith, Nature, 216, 706 (1967).

17) H. C. Froede and I. B. Wilson, "The Enzymes," 3rd Ed., ed. by P. H. Boyer, Vol. 5, Academic Press, New York, 1971, pp. 87 114.

18) B. Belleau and H. Tani, Mol. Pharmacol., 2, 411 (1966).

19) R. Kitz and I. B. Wilson, J. Biol. Chem., 238, 745 (1963).

20) H. P. Metzger and I. B. Wilson, J. Biol. Chem., 238, 3432 (1963).

21) I. B. Wilson, "The Enzymes," 2nd Ed., ed. by P. D. Boyer, H. Lardy and K. Myrbäck, Vol. 4, Academic Press, New York, 1960, pp. $501 \sim 520$.

22) I. B. Wilson and C. Quan, Arch. Biochem. Biophys., 73, 131 (1958).

23) J-P. Changeux, Mol. Pharmacol., 2, 369 (1966).

24) B. D. Roufogalis and E. E. Quist, Mol. Pharmacol., 8, 41 (1972).

25) D. R. Moss, D. E. Moss and D. Fahrney, Biochim. Biophys. Acta, 350, 95 (1974).

26) M. Zorko and M. R. Pavlič, Biochem. Pharmacol., 35, 2287 (1986).

27) D. M. Conning, K. Fletcher and A. A. B. Swan, Br. Med. Bull., 25, 245 (1969).

28) A. Silver, "The Biology of Cholinesterases," NorthHolland Publishing Co., Amsterdam, 1974, pp. $358 \sim 364$.

29) M. H. Litchfield, J. W. Daniel and S. Longshaw, Toxicol., 1, 155 (1973).

30) J. W. Langston, P. Ballard, J. W. Tetrud and I. Irwin, Science, 219, 979 (1983).

31) J. A. Javitch, R. J. D'Amato, S. M. Strittmatter and S. H. Snyder, Proc. Natl. Acad. Sci. U.S.A., 82, 2173 
(1985).

32) A. Barbeau, L. Dallaire, N. T. Buu, J. Poirier and E. Rucinska, Life Sci., 37, 1529 (1985).
33) D. Di Monte, M. S. Sandy, G. Ekstrom and M. T. Smith, Biochem. Biophys. Res. Commun., 137, 303 (1986). 